\title{
Book review* Inequality - What can be done?
}

Author:

Academic title:

Institution:

Title:

Year of publishing:

Publisher:

Number of pages:

Type of publication:

Type:

Language:

ISBN:
Anthony B. Atkinson

University Professor

London School of Economics and Fellow of Nuffield College, Oxford Inequality - What Can Be Done?

2015

Harvard University Press

400

Hardcover

Popular science book

English

978-0674504769

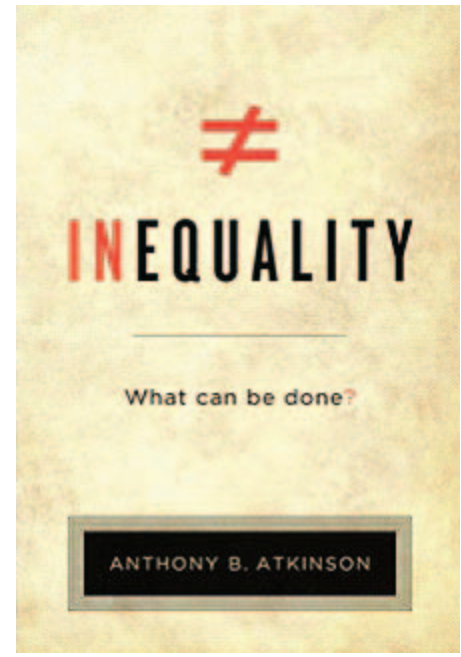

The book "Inequality - What Can Be Done?" has been written by Anthony B. Atkinson who is a Centennial Professor at the London School of Economics and Fellow of Nuffield College, Oxford, Fellow of the British Academy.

Prof. Atkinson is one of the most influential authors on inequality. This popular science book consists of 400 pages, divided in three parts: Diagnosis, Proposal for Action and Can It Be Done with 11 chapters. Beside these 11 chapters, there is an Introduction and the final part of the book entitled The Way Forward. At the end of the book, there is Glossary and a long list of the notes for each chapter. The book itself is written in a readable manner for development scientists, students of economics and general public.

The book is easy to read, with an approach that almost entirely avoids incomprehensible economic discourse (and for explanation of highly-professional economic terms, there is the Glossary). It is also very pragmatic: Atkinson is trying to find practical examples that can, in his opinion, move the economy in the right direction. Although the book is based on the case of the United Kingdom, examples provided in this book can be applied in many countries, especially Croatia.

Atkinson has been at the forefront of research on inequality for a long time, and brings his theoretical and practical experience to bear on its diverse problems. The

\footnotetext{
* Received: 23-05-2016; accepted: 17-06-2016
} 
problem, Atkinson shows, is not simply that the rich are getting richer. The main idea behind this book is that inequality is very important and that something can be done about it. In the past few years, Thomas Piketty has started with the trend of poverty analyses in popular science books and brought this topic more into the spotlight. This has triggered the global debate about inequality. The main difference between Piketty's and Atkinson's book is that Prof. Atkinson is writing more about solutions than problems of inequality (besides Piketty's statements about taxation of the wealthy).

The book starts with a diagnosis of inequality and explanation of household equalized disposable income, and the difference between household market incomes. According to the author, there is a rise in inequality in the United Kingdom of 10 percentage points from the early 1980 s, and inequality today is higher in comparison with the previous generation. Also, there has been a change in the distribution of income since the 1980s in the United Kingdom. One of the reasons why this happened is because of the demand and supply for educated workers (due to the globalization and technological development, there is a lack of demand for uneducated workers). The way to fix this is, of course, to invest more in education and scientific research. According to the author, the direction of technological change should be an explicit concern of policy-makers, encouraging innovation in a form that increases the employability of workers, emphasizing the human dimension of service provision.

Some of the other proposals are: Public policy should aim at a proper balance of power among stakeholders, and to this end should (a) introduce an explicitly distributional dimension into competition policy, (b) ensure a legal framework that allows trade unions to represent workers on level terms, and (c) establish, where it does not already exist, a Social and Economic Council involving the social partners and other non-governmental bodies. The government should adopt an explicit target for preventing and reducing unemployment and underpin this ambition by offering guaranteed public employment at the minimum wage to those who seek it. There should be a national pay policy, consisting of two elements: a statutory minimum wage set at a living wage, and a code of practice for above-minimum wage, agreed as part of a "national conversation" involving the Social and Economic Council, and a minimum inheritance paid to all at adulthood. Government should have a "Public Investment Authority" with the goal of building up the net worth of companies and its property, a more progressive rate for personal income tax, up to a top rate of 65 per cent. Receipts of inheritance and gifts should be taxed under a progressive lifetime capital receipts tax, a proportional, or progressive, property tax based on up-to-date property assessments. Child Benefit should be paid for all children at a substantial rate and should be taxed as income. Rich countries should raise their target for Official Development Assistance to 1 per cent of Gross National Income. Throughout the book, all the proposals are explained and defended against 
the common arguments and excuses for inaction that intervention will shrink the economy, that globalization makes action impossible, and that new policies cannot be afforded.

Alongside these proposals, there are several possibilities that need to be further explored; idea to pursue: a thoroughgoing review of the access of households to the credit market for borrowing not secured on housing; examination of the case for an "income-tax-based" treatment of contributions to private pensions, along the lines of present "privileged" savings schemes, which would bring forward the payment of tax; a re-examination of the case for an annual wealth tax and the prerequisites for its successful introduction; a global tax regime for personal taxpayers, based on total wealth; a minimum tax for corporations.

According to the author, the mentioned proposals are bold, but bold measures are required if, as in the case of the UK, a country wants to return to the levels of inequality before the turn of inequality in the 1980s. To get back to the time when the UK was ranked in the middle of OECD countries, and not among those at the high end of inequality, it is not enough to tinker with the existing instruments of economic and social policy. Major reforms are required, engaging all areas of economic and social life. In order to achieve this, the inter-relation between inequality and politics is crucial; however, Atkinson states that there may be ground for optimism.

The book has also received some negative reviews in the USA. Namely, according to the critics, the provided proposals cannot solve inequality problems and they would lead to the collapse of economies. However, Atkinson himself says that his proposals may be incomprehensible to those who believe that inequality problems can be solved by the market itself. This is especially visible in economies such as Croatian, which shows daily that the differences between the richest and the poorest are increasing and that something needs to be done. Some of the above-mentioned proposals are definitely applicable and necessary.

Reviewed by

Zoran Ježić, Assistant Professor

University of Rijeka, Faculty of Economics

Rijeka, Croatia 